\title{
A REVIEW OF SASKATCHEWAN CHRISTMAS BIRD COUNTS: 1942-1976 (PART I)
}

WAYNE E. RENAUD, LGL Ltd., environmental research associates, 44 Eglinton Ave. W., Toronto, Ontario M4R 1A1, and GUY J. WAPPLE, Box 1153, Biggar, Saskatchewan SOK 0M1.

This is the first of a two-part review that deals comprehensively with the large volume of information that has been collected during 35 years of Christmas Bird Counts since 1942 in Saskatchewan. Part I summarizes information about each of the 127 species that has been recorded during these counts.* Part II, which will appear in a future issue of the Blue Jay will discuss (1) the frequency and abundance of species within groups (waterfowl, raptors, etc.), (2) aspects of early winter species diversity, and (3) population changes that have occurred over the 35-year period.

In 1942, the Saskatchewan Christmas Bird Count became the first organized field activity of the newlyformed Saskatchewan Natural History Society. Prior to this time, published Christmas bird counts in the province had consisted of 14 reports (nine of which were from Eastend) between 1913 and $1941 .{ }^{4}$ Since 1942, these bird counts have generally followed the procedures developed by the National Audubon Society; however, for various reasons (the most important of which was likely the opportunity to publish the counts provincially) few counts were published in Audubon Field Notes or American Birds. Counts published in the Blue Jay from 1943 to 1977 form the basis of this review.

With few exceptions, we have incorporated all the information presented in the 946 counts reviewed in this paper. Counts from near the Saskatchewan border at Swan River,

\footnotetext{
*The annual summaries of Christmas Bird Counts have traditionally followed the 1957 A.O.U. Checklist and thus have recognized 129 species. ${ }^{1}$
}

Manitoba, have been excluded. One other count at Webb in 1965 was rejected as it seemed likely that the single Western Meadowlark was reported to the editor as an incidental observation rather than an actual count. Responsibility for the accuracy of these records lies soley with the observers.

We have evaluated the status of each species recorded during the past 35 years of Saskatchewan Christmas Bird Counts by looking at five aspects of each species' occurrence: regularity, frequency, abundance, high counts (and area) and early winter distribution. Each species account presents the following information:

1) regularity (number of years recorded),

2) frequency (number of counts during which the species was recorded on count day or as an additional species),

3) abundance (total number of individuals recorded on count days),

4) high count (largest number of individuals reported, together with the locality and date, on count day or as an additional species during count period),

5) all observations of species recorded fewer than six times during count period,

6) northermost or southermost observations (if applicable); this information does not appear for species covered by distribution maps. Fig. 1 shows the locations of all localities mentioned in the text.

To provide an indication of relative status, the 60 most frequently recorded and the 60 most abundant species have been ranked in descending order of importance in the annotated 
Table 1. Thirty most frequently recorded and 30 most abundant species observed on Christmas Bird Counts in Saskatchewan, 1942 to 1976. See Table 2 for ranks beyond 30 . ( $T=$ tied)

\begin{tabular}{cc}
\multicolumn{2}{c}{ Rank } \\
$\begin{array}{c}\text { Fre- } \\
\text { quency }\end{array}$ & $\begin{array}{c}\text { Abun- } \\
\text { dance }\end{array}$ \\
1 & 6 \\
2 & 1 \\
& \\
3 & 11 \\
4 & 2 \\
5 & 10 \\
6 & 3 \\
7 & 18 \\
8 & 8 \\
9 & 21 \\
10 & 12 \\
11 & 4 \\
12 & $25 \mathrm{~T}$ \\
13 & 22 \\
14 & 27 \\
15 & 5 \\
16 & 20 \\
17 & 14 \\
18 & 13
\end{tabular}

\begin{tabular}{|c|c|c|}
\hline & \multicolumn{2}{|c|}{ Rank } \\
\hline & $\begin{array}{c}\text { Fre- } \\
\text { quency }\end{array}$ & $\begin{array}{l}\text { Abun- } \\
\text { dance }\end{array}$ \\
\hline Starling & 19 & 15 \\
\hline Northern Shrike & 20 & \\
\hline Common Raven & $21 \mathrm{~T}$ & 16 \\
\hline Ring-necked & & \\
\hline pheasant & $21 \mathrm{~T}$ & 19 \\
\hline Gray Jay & 23 & 29 \\
\hline Golden Eagle & 24 & - \\
\hline Mallard & 25 & 7 \\
\hline Goshawk & 26 & - \\
\hline Short-eared Owl & 27 & - \\
\hline Hoary Redpoll & 28 & $25 \mathrm{~T}$ \\
\hline White-breasted & & \\
\hline Nuthatch & 29 & - \\
\hline Merlin & 30 & - \\
\hline Canada Goose & - & 9 \\
\hline Common Goldeneye & - & 17 \\
\hline $\begin{array}{l}\text { White-winged } \\
\text { crossbill }\end{array}$ & - & 23 \\
\hline Cedar Waxwing & - & 24 \\
\hline Red Crossbill & - & 28 \\
\hline Lapland Longspur & - & 30 \\
\hline
\end{tabular}

${ }^{1}$ Based on 921 counts; range from Black-billed Magpie ( 844 counts, rank $=1$ ) to Merlin (82 counts, rank $=30$ ).

${ }^{2}$ Based on 916 counts; range from House Sparrow $(217,058$ individuals, rank $=1$ ) to Lapland Longspur (259 individuals, rank $=30$ ).

${ }^{3}$ See Additional Notes at end of Annotated List.

list of Table 2 . The 30 most frequently recorded and 30 most common species are shown in Table 1. Where two or more species are tied for frequency or abundance, this is also indicated.

Both ranking proceedures were used because a rank based on frequency often is not a reliable indication of a rank based on abundance. $A$ major factor explaining this apparent anomaly is the species' social habits. A dispersed species, e.g., Hairy Woodpecker, usually has a frequency rank much higher than its abundance rank, and is typically recorded in small numbers on a large number of counts. Conversely, a highly gregarious species, e.g., Bohemian Waxwing, usually has a much higher abundance than frequency rank, and is recorded in large numbers on a relatively smaller number of counts. In fact, the Hairy Woodpecker was the 9 th most frequently recorded but only 21st most abundant species; the Bohemian Waxwing was the 11th most frequently recorded but 4 th most abundant species. Clearly, both frequency and abundance must be considered in evaluating the status of a species.

Only counts completed within the official count period in each year have been included in the calculation of regularity, frequency, abundance, high counts and lists of all observations of rare species. Counts longer than a day, e.g., counts recording maximum numbers of each species observed during Christmas week, are excluded from data used to determine abundance. Where more than one count was submitted from one location in one year, the count with the highest species total on the day of the count was considered as count day. Species observed only on other counts completed at that location in that year were considered to be ad- 


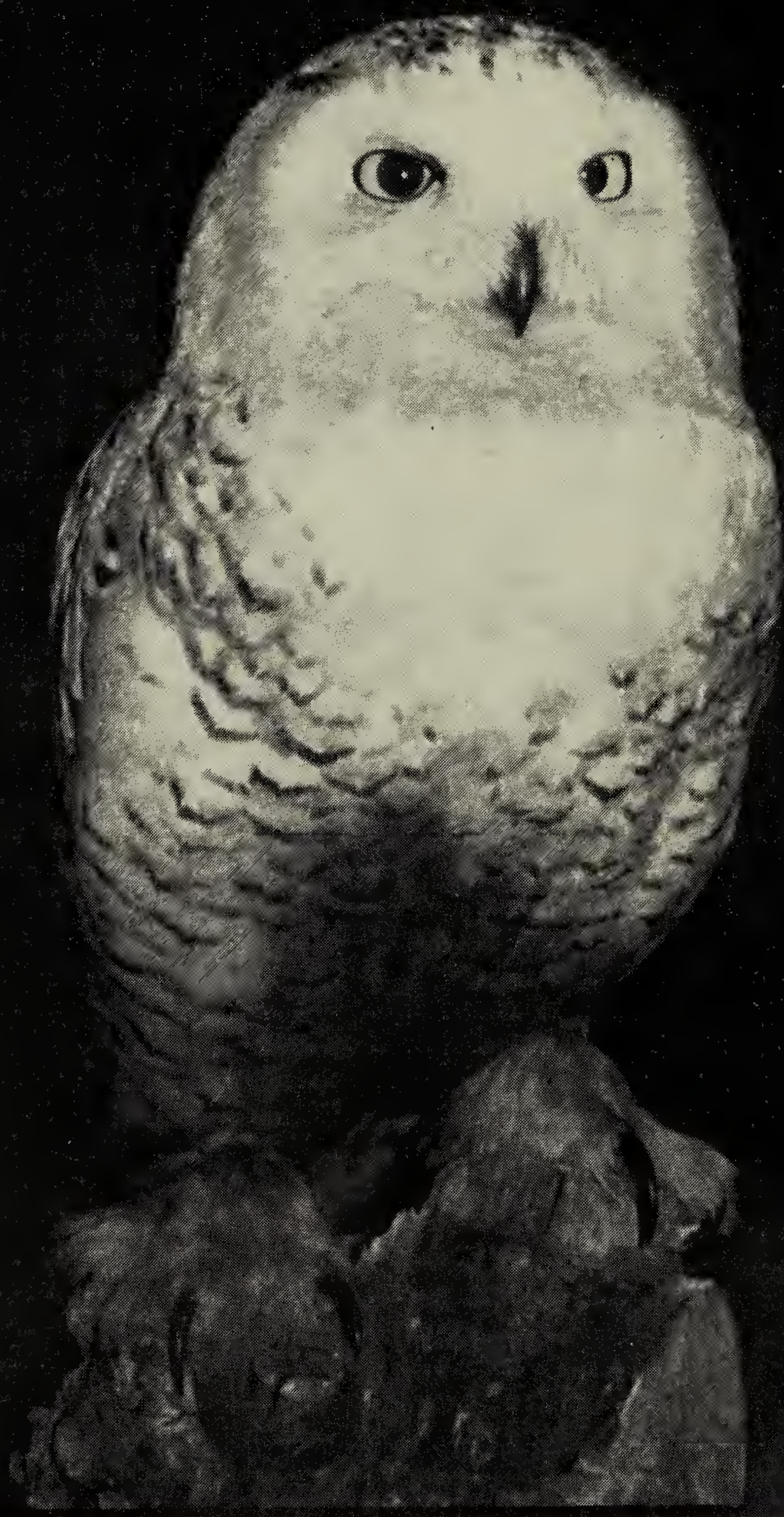




\section{$\frac{0}{4}$
$\frac{0}{0}$
n}

Red-neck Grebe Horned Grebe Eared Grebe

Western Grebe

Pied-bill Grebe

White Pelican

Am Bittern

Mute Swan

Whistling Swan

Trumpeter Swan

Canada Goose

White-fr Goose

Snow Goose

Ross' Goose

* Mallard

Black Duck

Gadwall

Pintail

Green-wgd Teal

Blue-wgd Teal

Am Wigeon

N Shoveler

Redhead

Canvasback

Greater Scaup

* Lesser Scaup

Bufflehead

Oldsquaw

Wh-wgd Scoter

Ruddy Duck

Hood Merganser

Com Merganser

Red-br Merganser

Goshawk

Sharp-sh Hawk

Cooper's Hawk

*Rough-leg Hawk

* Golden Eagle

*Bald Eagle

Marsh Hawk

Gyrfalcon

* Prairie Falcon

Peregrine Falcon

* Merlin

Am Kestrel

* Spruce Grouse

* Ruffed Grouse

*Willow Ptarmigan

Sage Grouse

*Ring-nk Pheasant Chukar

*Gray Partridge
* Com Goldeneye

* Sharp-t Grouse$$
1
$$

*See Distribution map.

${ }^{2}$ Two-way tie.

${ }^{3}$ Three-way tie.

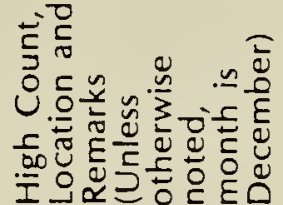

Regina 28/68

Regina 26/59 \& 26/60 \& 24/61

Regina 30/62. All Regina.

Regina 26/56 \& 26/69

Regina $27 / 55 \& 26 / 73$. All Regina.

Regina $26 / 59 ; 1$ on $26 / 67 \& 26 / 69$. (All)

Yorkton 26/53. Injured.

Regina 26/58. All Regina.

Regina Jan. 3/65. All Regina.

Regina Jan. 3/65.

Regina 26/75. N to Kutawagan Lake.

In Regina annually 1955-1976

Saskatoon 26/74

Regina 26/74

Regina $30 / 62$ \& 26/74

Regina $28 / 63$

Regina 26/73

Regina 24/61 \& Jan. 3/65 CP 2 Regina 24/63. N to Saskatoon

Regina 26/56 \& 27/55 \& 26/60, Saskatoon $26 / 74$. North to Saskatoon

2 Saskatoon 26/74; CP 1 Regina/55, /56 \& (All)

(1 inj) Regina 30/62. All Regina

Regina 28/63. N to Saskatoon

Regina 26/75; 1 Regina 30/62, Saskatoon

$26 / 67 \& 26 / 74$. All observations.

Regina 26/69. N to Saskatoon

Regina 26/70. N to Saskatoon

Regina 26/74

Regina $27 / 71$

Saskatoon 26/76

Regina 26/73, 1 Regina 26/69. CP 1 Reg/60 \& 74. (AlI)

CP 1 Ft. Qu'Appelle 21/68; collected, 1st Saskatchewan record.

Cold River $15 / 74$

Regina 30/62. All Regina

Estevan 30/60; 2 Gardiner Dam 20/72;

$1 \operatorname{Reg} 26 / 74$. (AII)

Gardner Dam 30/76. N to Squaw Rapids

and Cold River

2 Regina 26/56 \& Saskatoon 26/73;

1 Regina 26/69. CP 2 Ft. Qu'Appelle 24/69. (All)

5 Yorkton 26/43 \& Little Bear Lake 26/58 Carlton 30/56 \& Moose Jaw 26/70 \& Big Gully 18/74. CP 1 Nipawin-Squaw Rapids 26/69. (All)

CP 1 Battleford 28/59

Val Marie 26/66

Skull Creek 26/69

Nipawin-Squaw Rapids 26/69

per count. N to Harris, Kenaston,

Hawarden.

Gull Lake, Harris, Lady Lake, Last Mt.

Lake, Reg, Saskatoon (2 yrs), White Bear

per count. CP 2 Regina/60, Skull Creek/76

per count. N to Squaw Rapids-Carrot R.

Saskatoon 26/72 \& 26/75

Lumsden 29/58 \& Skull Creek 27/69.

CP 1 Spring Valley $17 / 72$

Nipawin 31/48

Battleford 26/60

Stony Rapids 31/71

Harris 17/72. See below.

Shaunavon Jan. 1/62 \& Masefield 27/62.

$\mathrm{N}$ to Maple Creek

Woodrow $26 / 59$

Lumsden 29/58; 7 Battleford 29/47.

(All). See below.

Saskatoon 26/70 
Am Coot

Glaucous Gull Herring Gull Ring-bill Gull

Rock Dove

* Mourning Dove

* Great Horn Owl

* Snowy Owl

*Hawk Owl

Barred Owl

Great Gray Owl

*Long-eared Owl

*Short-eared Owl

Boreal Owl

*Saw-whet Owl

${ }^{*}$ Common Flicker

*Pil Woodpecker

* Hairy Woodpecker

* Downy Woodpecker

*B-b 3-t Woodpeck

*N 3-t Woodpecker

*Horned Lark

* Gray Jay

* Blue Jay

*BI-bill Magpie

*Common Raven

*Common Crow

*BI-cap Chickadee

Mount Chickadee

* Boreal Chickadee

*Wh-br Nuthatch

* Red-br Nuthatch

* Brown Creeper

North Mockingbird

Brown Thrasher

*Am Robin

Mount Bluebird

Town Solitaire

* Gold-cr Kinglet

Ruby-cr Kinglet

* Bohemian Waxwing

* Cedar Waxwing

* Northern Shrike

*Starling

Yel-rump Warbler

* House Sparrow

*West Meadowlark

*Red-wg Blackbird

* Rusty Blackbird

* Brewer Blackbird

* Common Grackle

Brown-h Cowbird

Cardinal

* Evening Grosbeak

Purple Finch

*Pine Grosbeak

Gray-c Rosy Finch

*Hoary Redpoll

* Common Redpoll

*Pine Siskin

* Red Crossbill

*Wh-wgd Crossbill

Ruf-side Towhee

Vesper Sparrow
19

$8 \quad 12$

5

35
15

7

12

8

19

31

35

35

16

17

32

35

35

35
33

33
19

35

1
31
30

15

53

23

2
73

1 -

$\begin{array}{rr}68 & 47\end{array}$

422

422
38

38
172

208

208
781

781

17

24

56

27

$14-$

1
1

255

9
437

9
437
4

541

541

29

51

51
$54^{2} \quad 71 \quad 51$

- 4 -

-

15

-

14

$\begin{array}{rr}\frac{4}{4} & - \\ 21462 & - \\ 10 & - \\ 555 & 25^{2} \\ 521 & 27 \\ 12 & -\end{array}$

$$
1
$$

6

$\begin{array}{rl}8 & - \\ 191 & 38 \\ 6 & - \\ 5 & - \\ 55 & 55\end{array}$

$35 \quad 60^{2}$

874

1146

17

35
5688

448

874

17007

1548

66

8524

1
253

253
124

217

36
$54^{2}$

$29 \quad 32$

1
194

19

6
213

1

68329

582

153

2524

217058

$61^{3} \quad 12$

$52^{2} \quad 71$

206

58

$13 \quad-$

- -

3725

26
7550

14

-

40

555

555
72785

72785
193

471

$25^{2}$

25
3
37
28

702
11

3

1846

11

11
15
2

2

1

2$$
\begin{array}{r}
2 \\
23
\end{array}
$$

1
6

6

2

13

23

23
7

7

519
67

25

381

195

33

218

1

31
4

4

60

5

1

44

1

45

12442

90

90
6

124

1
333

3

30
38

23

3

1

202

14

422

140

62

3651

50
235

230

230
1

Regina 28/63. All Regina except 2 at Gardiner Dam \& Ft. Qu'Appelle

Gardiner Dam 22/75 \& 1 on $30 / 76$ (AII)

CP 1 Regina $30 / 56$

Saskatoon 26/58. CP 1 Regina 23/69 (All)

Saskatoon $27 / 71$. See below

Round Lake $28 / 75$

Harris $19 / 71$

Regina 26/75

Masefield $30 / 60$. CP Nipawin 31/56;

Radisson 20/69

Klogei Lake-High Hill 27/59. CP 1

Radisson 20, 27/68 \& Regina 23/69 \&

$31 / 72$

Nipawin 29/73. 1 Carrot River, Cowan L Cowan R, Nipawin (twice), Nipawin-

Squaw Rapids, Pas Trail, Saltcoats

Shaunavon 23/60. CP 3 Masefield 23/62

Regina 26/69

per count. South to Dilke, $N$ to Nipawin

per count.

Regina 26/67. Only "Red-Shafted" was at Regina $26 / 70$

Nipawin $26 / 42 \&$ Wallwort Jan. $1 / 45 \&$ Somme $26 / 53 \&$ Big River $30 / 55$. CP 2

Nipawin/52 \& Big River 26/58 \& 30/59

Saskatoon $26 / 72$

Saskatoon $26 / 73 \& 26 / 76$

Somme 27/52

Somme 27/52

Moose Jaw 26/68

Besnard Lake $27 / 74$

Saskatoon 26/70

Saskatoon $26 / 74$

Besnard Lake 27/74

Prince Albert $27 / 57$ (9 ravens also):

5 Moose Jaw $26 / 62$

Saskatoon $26 / 73$

Piapot 28/66

Besnard Lake 27/74

Wallwort Jan. $1 / 45$ \& Somme $27 / 52$

\& Big River $31 / 52$ \& Moose Jaw

$26 / 62$ \& Spirit Lake 29/63

Fort Walsh 31/76

Fort Walsh $31 / 76$

Regina 26/67

Saskatoon 26/60. CP 1 Regina 21/68

Saskatoon $26 / 70$

CP 1 Ft. Qu'Appelle 26/73

Regina (4 yrs.), Moose Jaw, Ft. Walsh

Big Gully Creek 19/74

Biggar 16/72

Saskatoon $26 / 75$

Saskatoon $26 / 75$

Saskatoon 26/63 \& Pike Lake 28/69

Moose Jaw 26/68 
*Dark-eyed Junco

24

*Tree Sparrow

Harris Sparrow

Wh-cr Sparrow

Wh-thr Sparrow

Fox Sparrow

* Song Sparrow

* Lapland Longspur

* Snow Bunting
41

45

-

-

-
50

26/53 Only 3 "Oregon" records: 2 Saskatoon 26/58, CP 1 Moose Jaw 23/63, CP 1 Ft. Qu'Appelle Jan. 1/64

Skull Creek 30/56

per count. $N$ to Nipawin

Saskatoon $26 / 74$

per count. $N$ to Nipawin

CP 1 Val Marie 22/67

per count

Caron 27/71

Nipawin 26/52 ditional species, i.e., species observed during count period but not on count day. Counts with slightly different count names such as Nipawin Squaw Rapids and Nipawin - White Gull Creek were maintained as separate counts.

Distribution maps are included for 63 of 75 species recorded more than nine times during the 35-year period. The Rock Dove was not mapped because it was not counted prior to 1958. Eleven species of waterfowl were excluded because they were very locally distributed. All localities are given for species recorded fewer than six times. Northernmost or southernmost locatlities are provided for species noted six to nine times and for species recorded more than nine times but for which accompanying distribution maps are not included.

The information used to draw the distribution maps followed the same general criteria as those used to determine frequency except that counts completed in Saskatchewan outside the official count period were also used. It was felt that these counts provided significant additional information on early winter distribution of several species.

A total of 946 counts was reviewed for this summary; 945 were published in the Blue Jay and the other (from Black Lake in 1972) was published in American Birds. A total of 920 counts was used to evaluate regularity and frequency and to establish high counts for common species and lists of all observations for rare species;
916 counts were used to establish abundance; and distribution maps are based on 933 counts.

Information on the number of hours spent counting and miles travelled was often not provided; therefore, analysis by party-hours (the procedure used in American Birds to map distribution) or party-miles could not be used here. The small number of observers participating in most counts often resulted in a small number of species on count day and a relatively large number during count period when additional species are included. We felt that, for mapping purposes, the most accurate indication of a species' frequency in an area was its presence during the count period (i.e., either on count day or as an additional species).

The distribution maps show the frequency of occurrence of each species in blocks that are two degrees longitude by one degree latitude; these areas, referred to here as degree blocks, are based on the $1: 250,000$ scale maps published by the Surveys and Mapping Branch, Department of Energy Mines and Resources. The total number of counts in each degree block is presented on the first distribution map. The percent of counts on which a species was recorded (during count period) is presented diagrammatically in the circle contained in each degree block.

To provide more accurate range information for the earlier years, the 


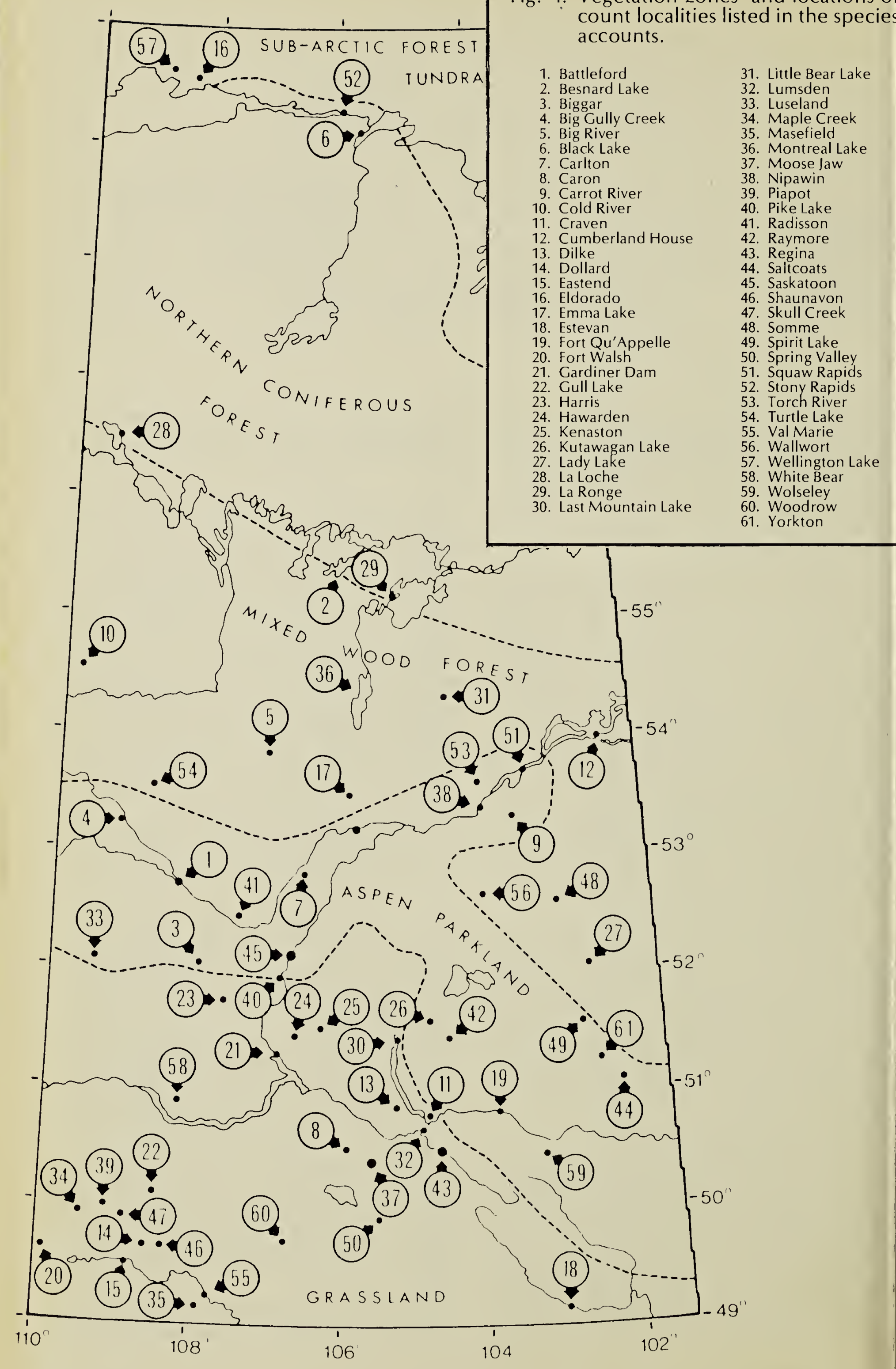

Fig. 1. Vegetation zones ${ }^{5}$ and locations of count localities listed in the species accounts.

Battleford

Little Bear Lake

32. Luseland

4. Maple Cree

Saskatoon

0. Spring Valley

Squaw Rapids

54. Turtle Lake

. ValMarie

Wallwort

(lington Lake

0. Woodrow

. La Ronge

(1)




\section{DISTRIBUTION MAPS}

SHADED PART OF EACH CIRCLE REPRESENTS PER CENT OF COUNTS ON WHICH THE SPECIES WAS RECORDED DURING COUNT PERIOD, 1942 TO 1976.

CIRCLES ARE SMALLER IN DEGREE BLOCKS WITH FEWER THAN 10 COUNTS
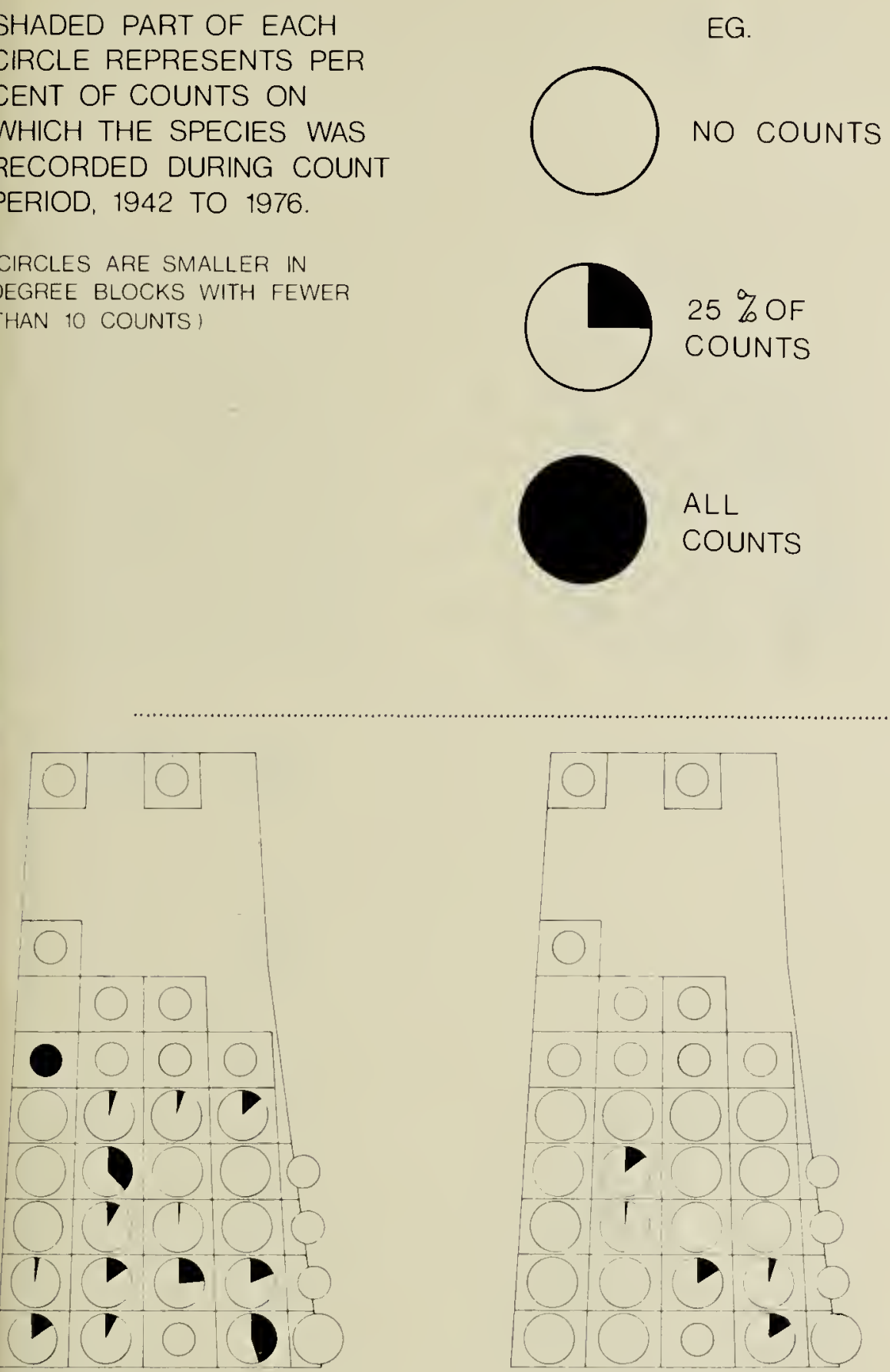

MALLARD

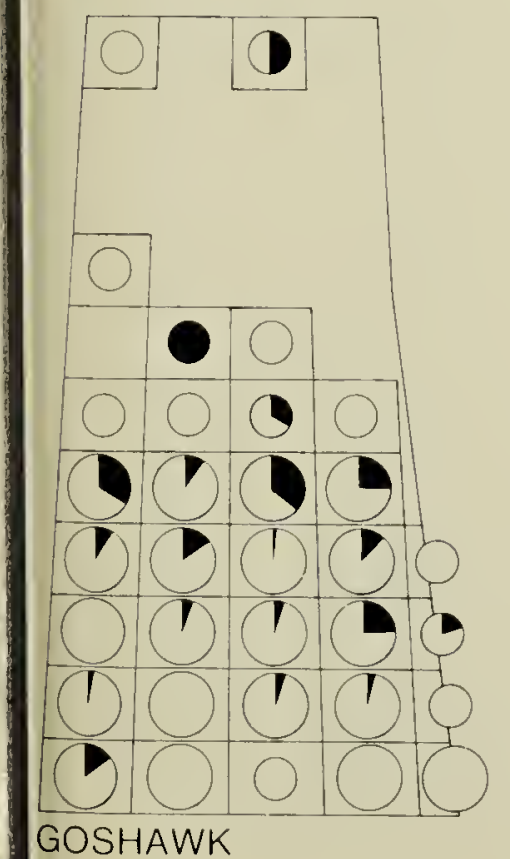

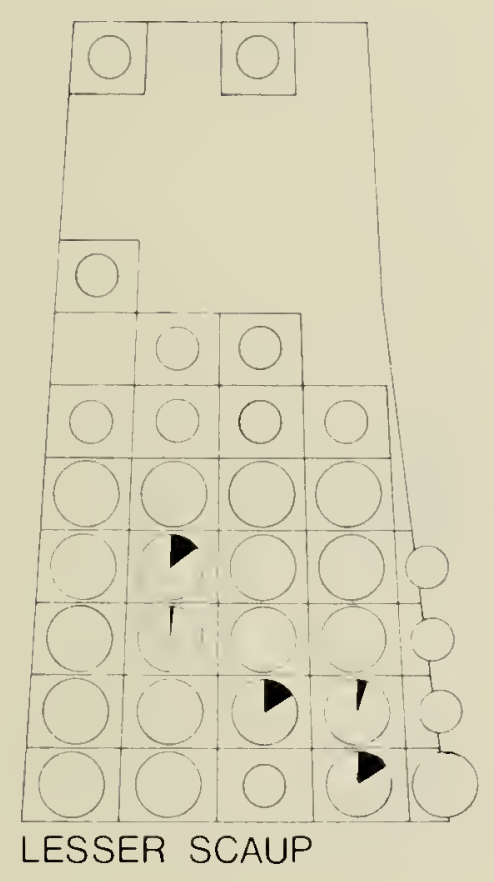
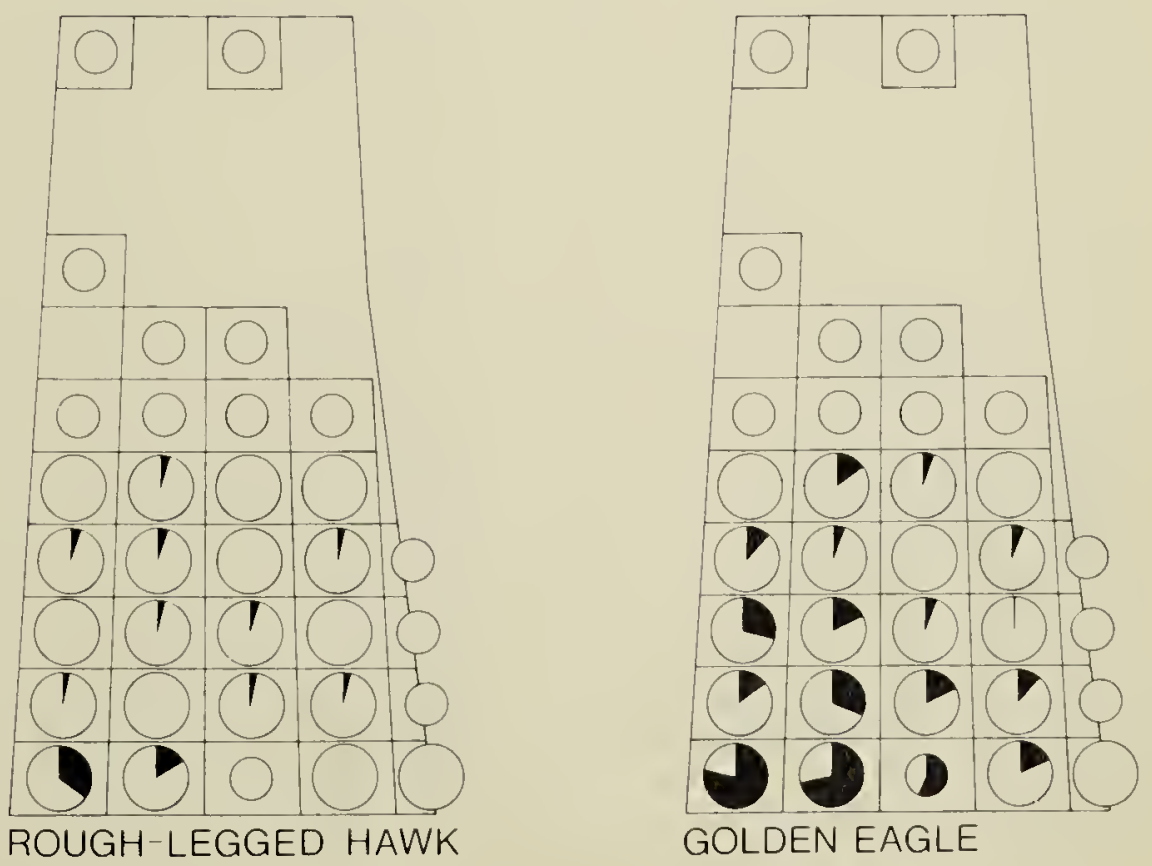
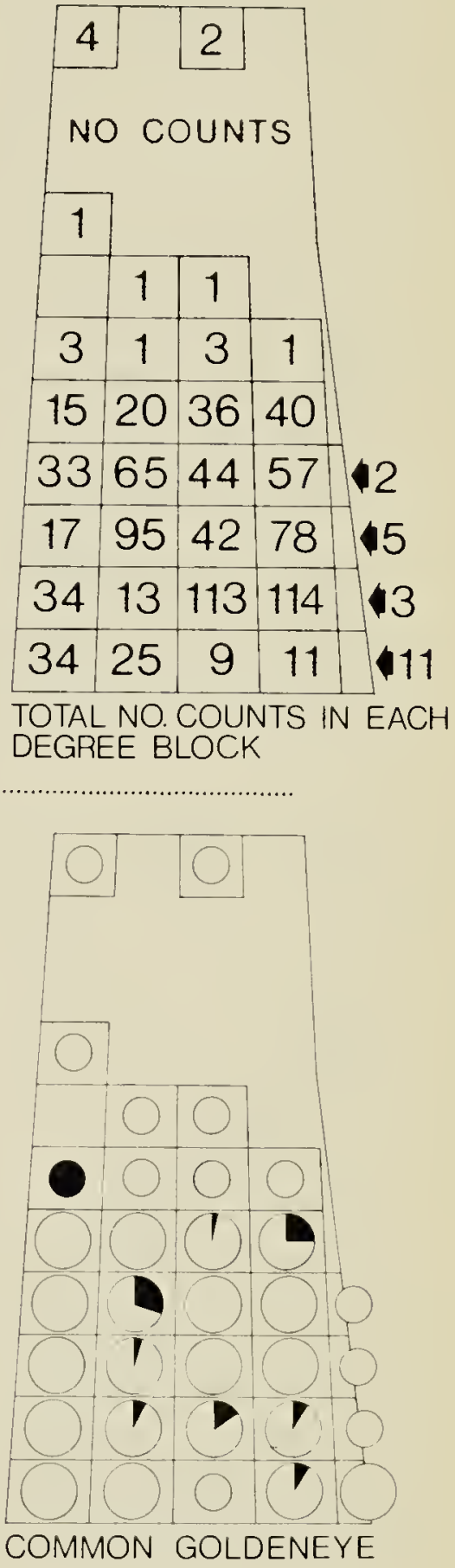

COMMON GOLDENEYE

GOLDEN EAGLE 


\section{DISTRIBUTION MAPS}
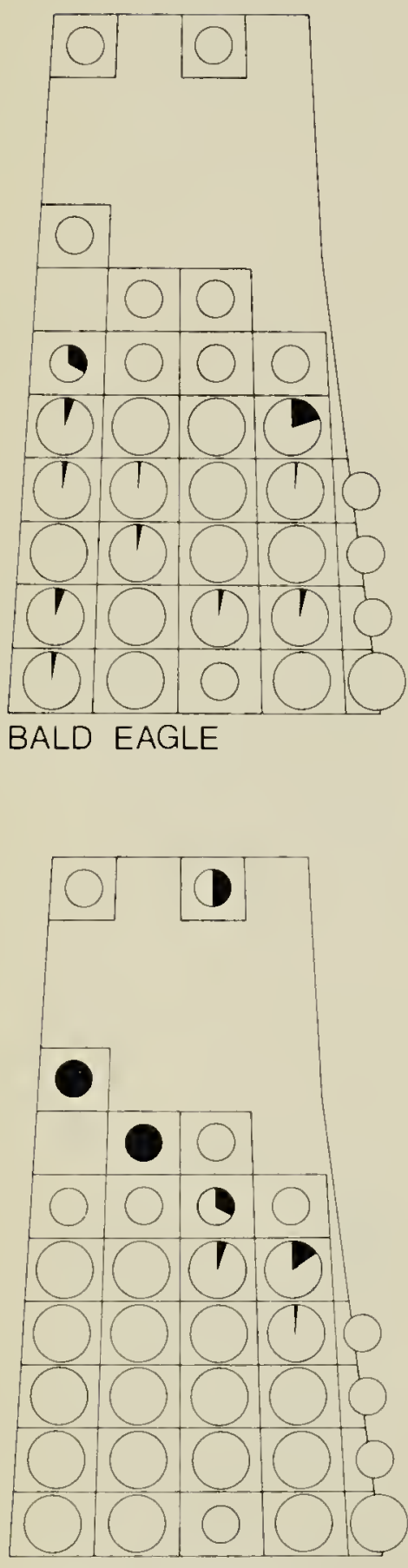

SPRUCE GROUSE

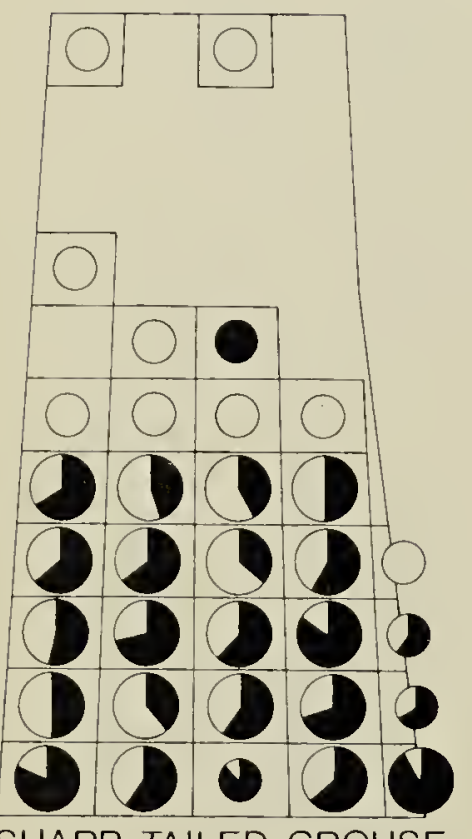

SHARP-TAILED GROUSE
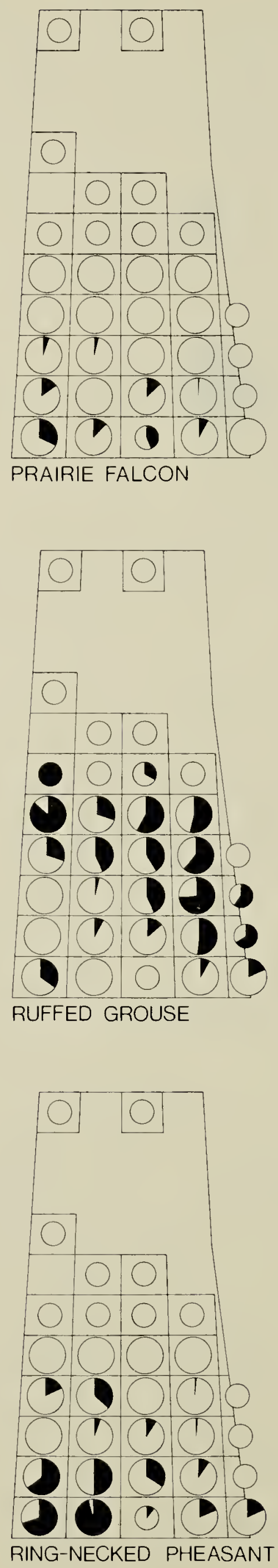
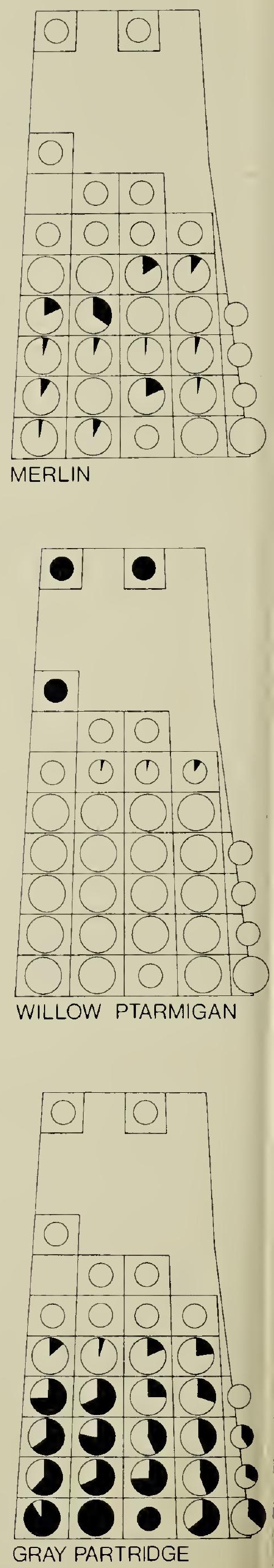

Blue Jay 


\section{DISTRIBUTION MAPS}
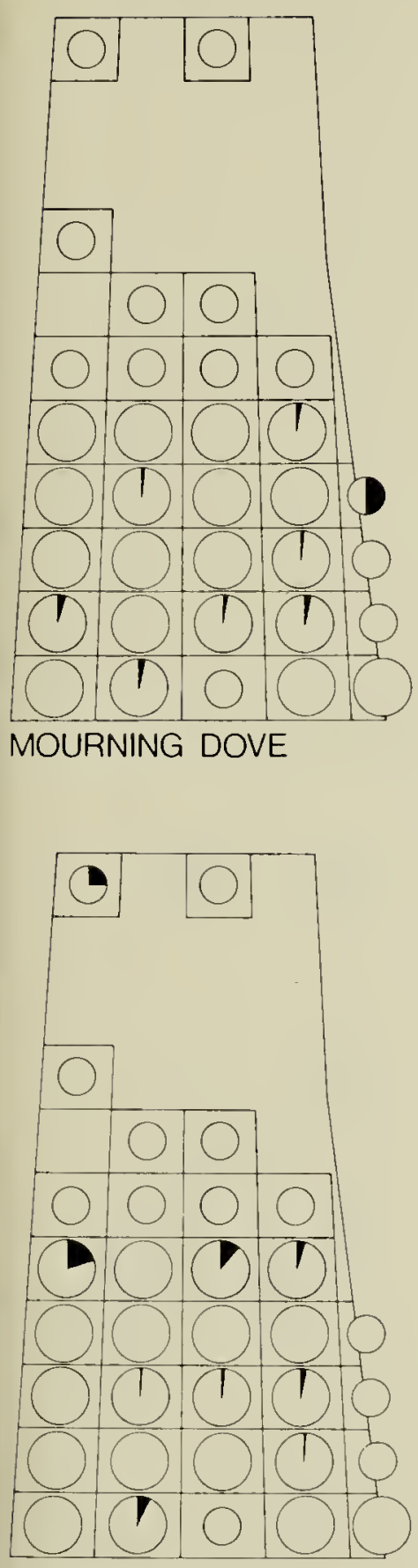

HAWK OWL

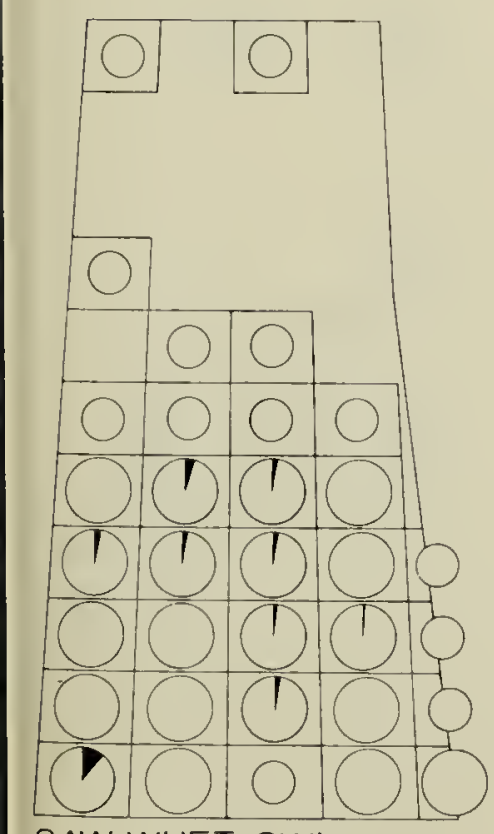

SAW-WHET OWL
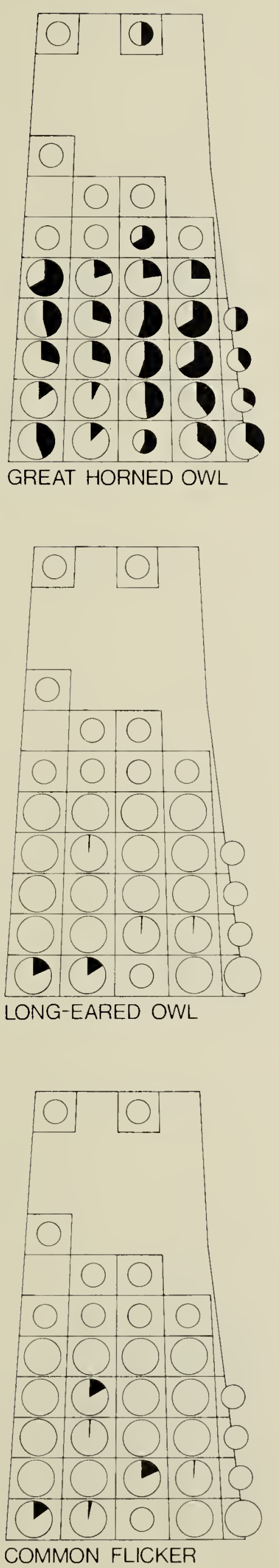
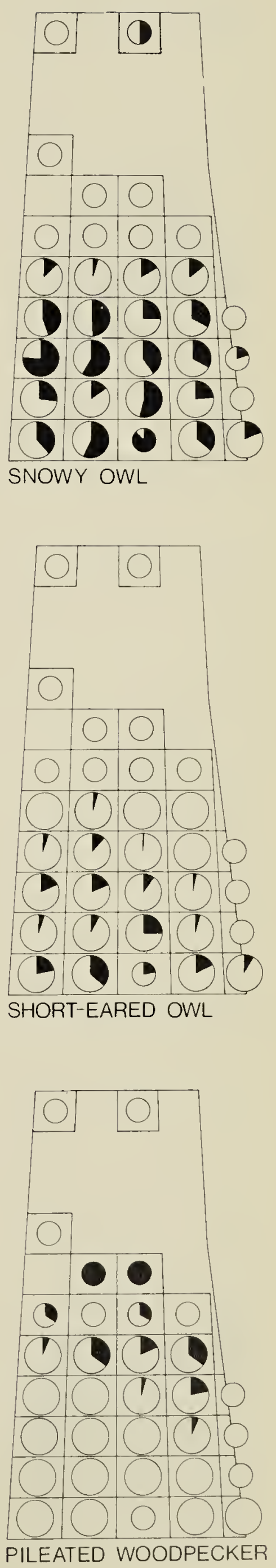
DISTRIBUTION MAPS

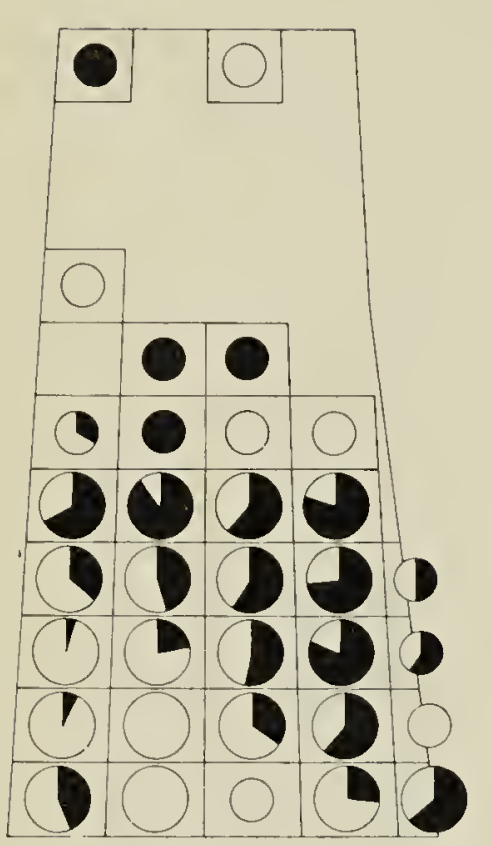

HAIRY WOODPECKER

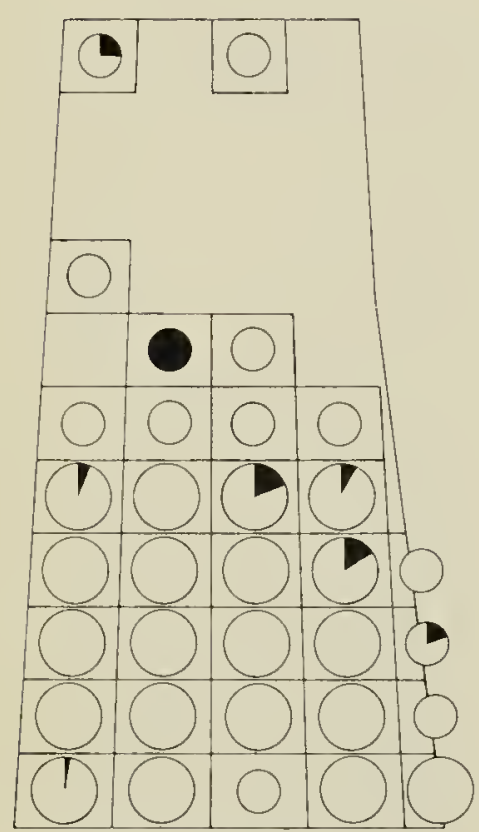

NORTHERN 3-TOED WOODPECKER

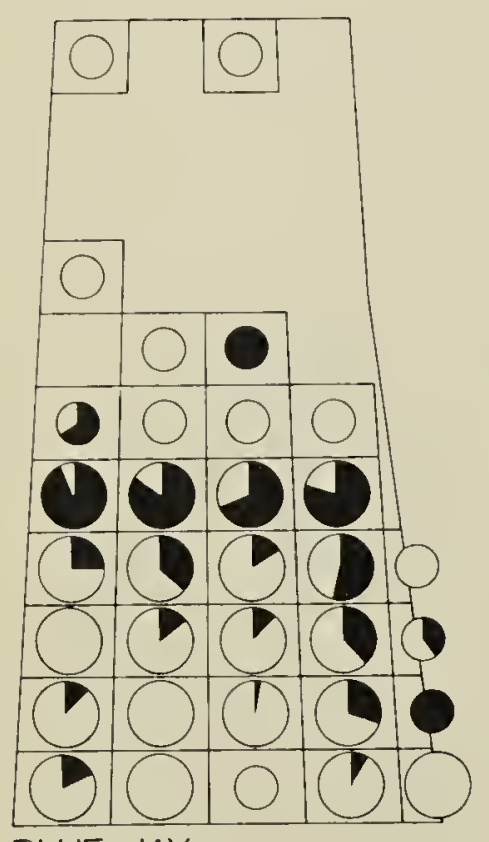

BLUE JAY
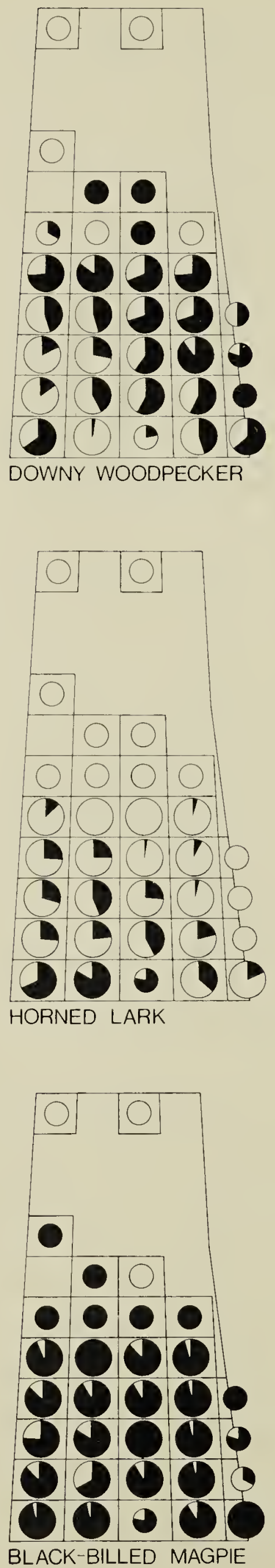
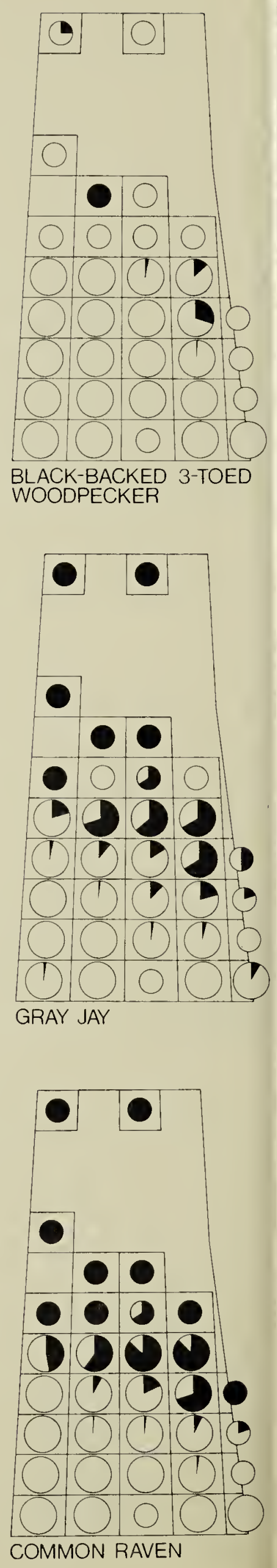

Blue Jay 


\section{DISTRIBUTION MAPS}
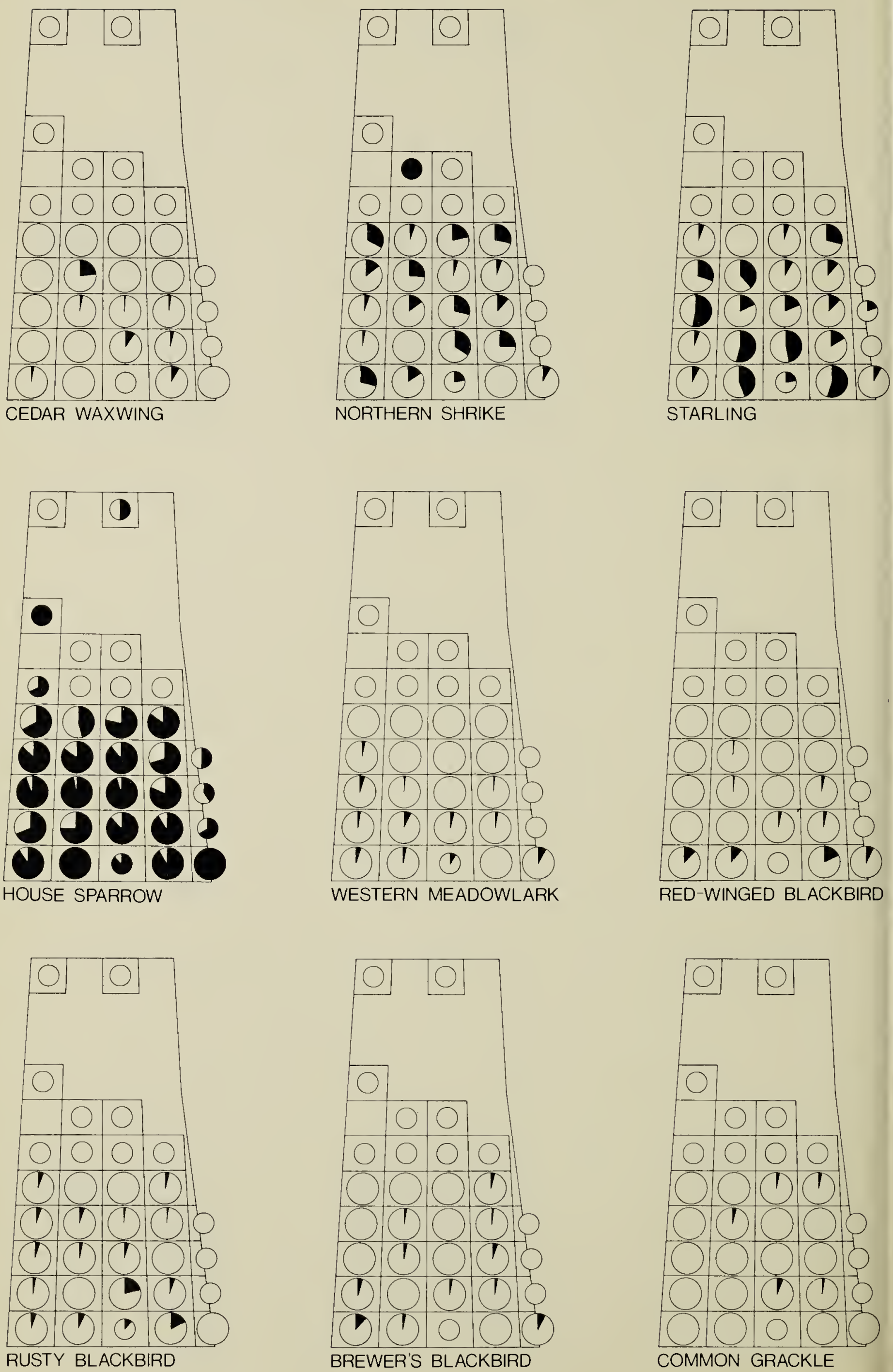


\section{DISTRIBUTION MAPS}

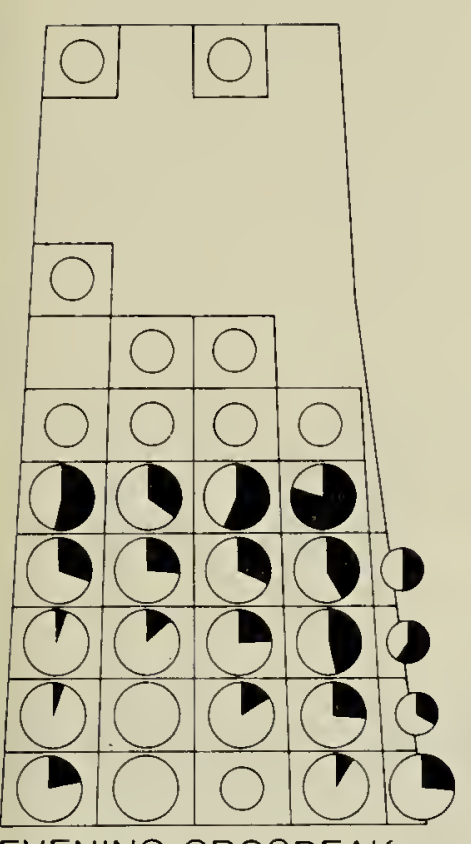

EVENING GROSBEAK

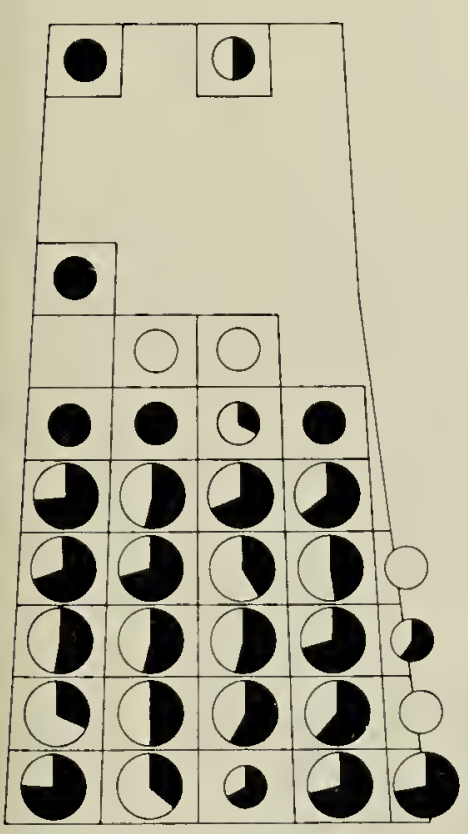

COMMON REDPOLL

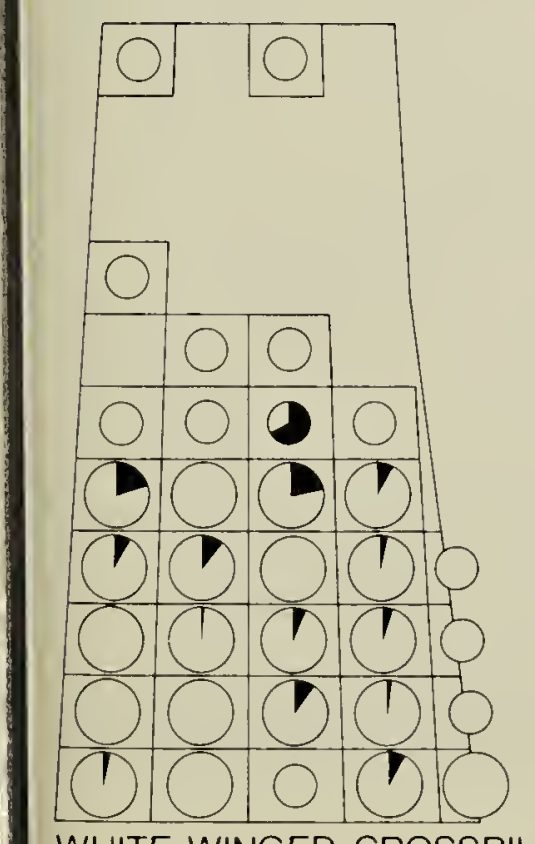

WHITE-WINGED CROSSBILL

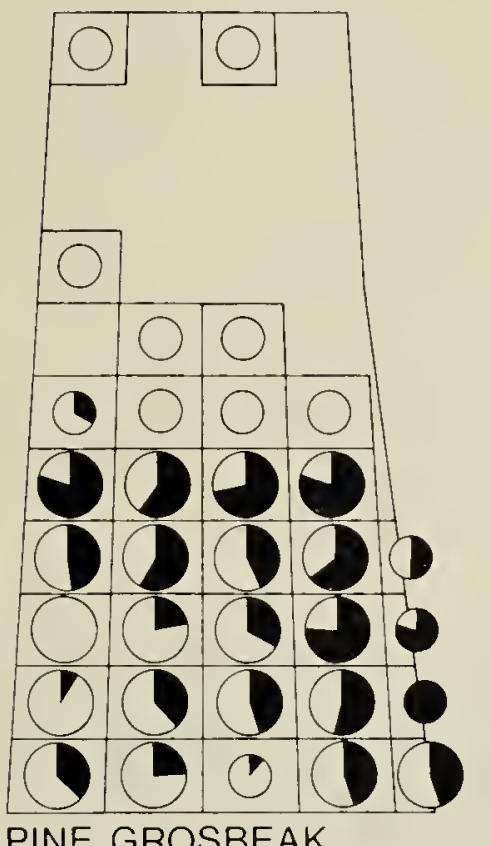

PINE GROSBEAK
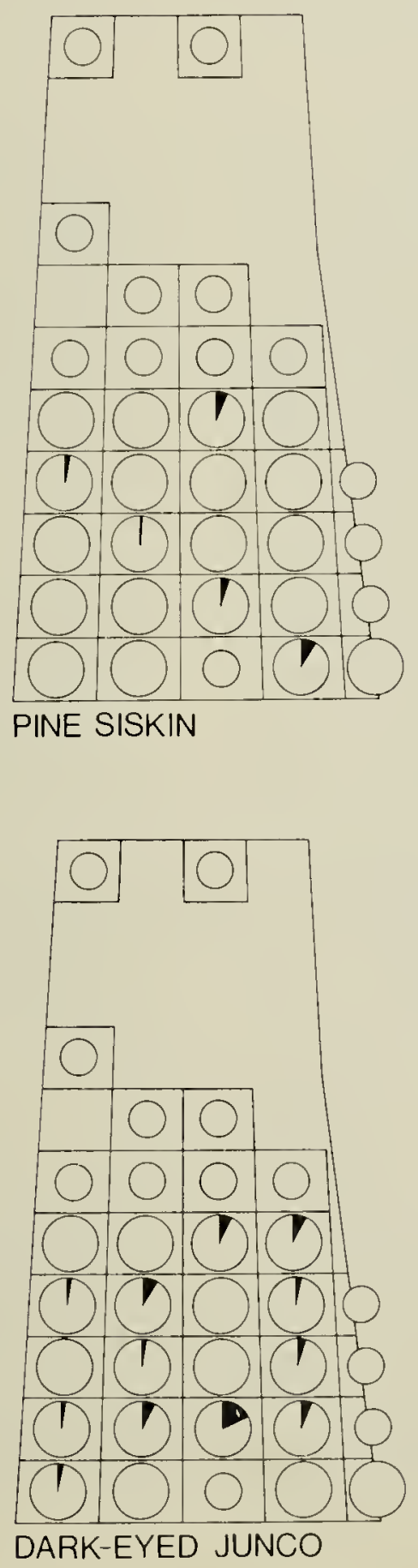
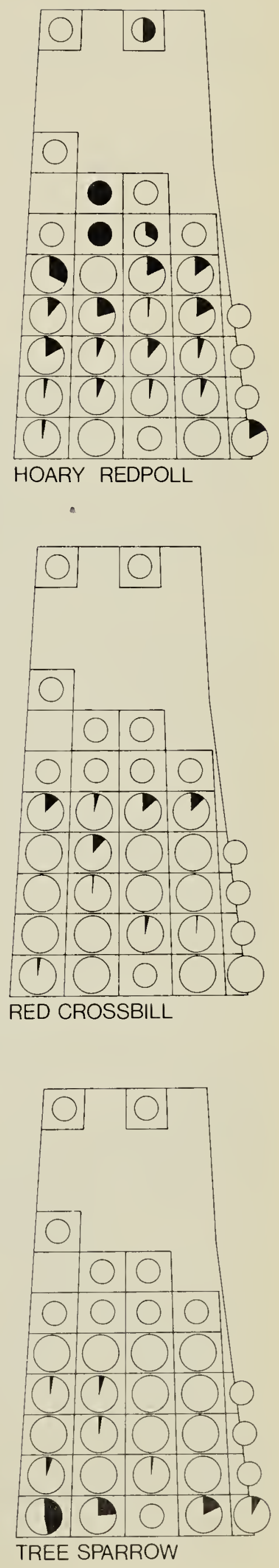


\section{DISTRIBUTION MAPS}

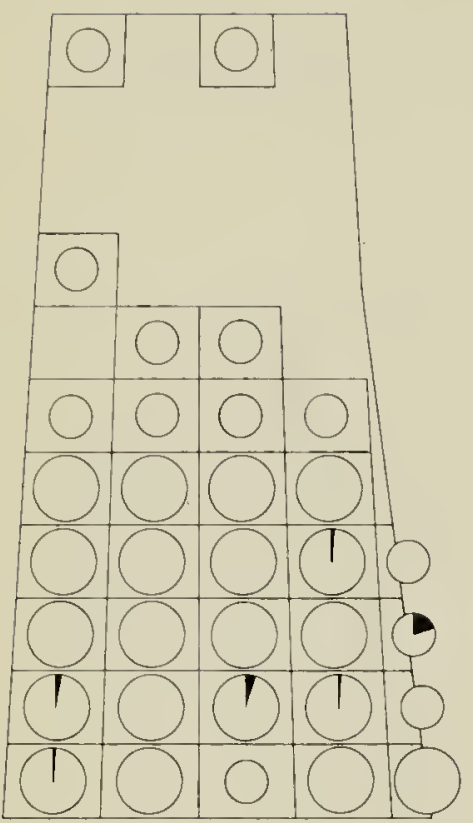

SONG SPARROW

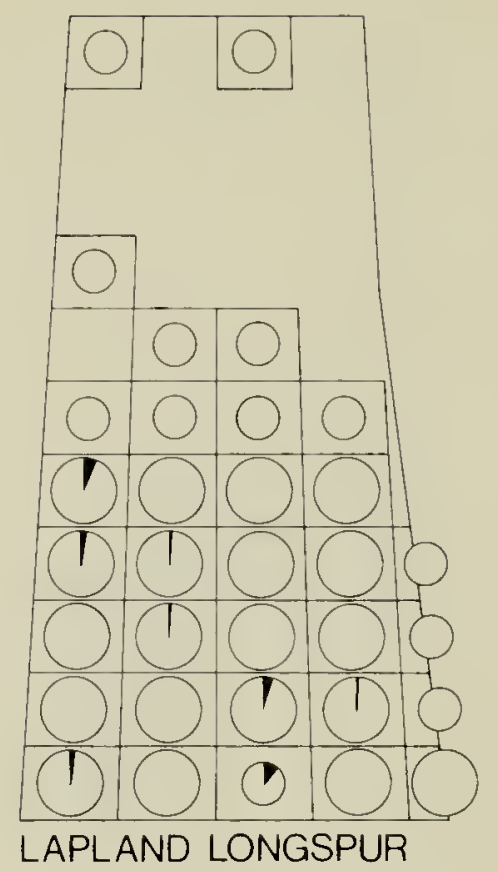

distribution maps have incorporated observations of species that were present during the latter half of December or early January, but not necessarily during Christmas week. When organized Christmas Bird Counts were first undertaken in the early 1940's, the count period was relatively short, extending only from Christmas Day to New Year's Day. This period was later lengthened to 14, then 16 days from mid-December to early January.

An example of the regularity, frequency and abundance summary is as follows:

HAIRY WOODPECKER. 35 years; 439 counts (rank, 9); 874 individuals (rank, 21). This indicates that the Hairy Woodpecker was recorded in all 35 years; on 439 of a possible 920 counts (making it the 9th most-frequently recorded species); with a total of 874 individuals on count day (making it the 21st most abundant species).

Common names of species and the order in which they are presented follow the latest American Ornithologists' Union Checklist and revisions ${ }^{1} 23$; thus Red-shafted and Yellow-shafted Flicker are regarded as one species, Common Flicker; Oregon and Slate-colored Junco are treated together under Dark-eyed Junco. Each of these four subspecies has been recorded at least once on Saskatchewan Christmas Bird Counts. Subspecific common names are maintained in the respective species accounts.

Within the province of Saskatchewan 121 species have been recorded on count day and six species have been recorded as additional species during count period. In the following annotated list, count period observations (made during count period but not on count day) are preceded by CP; often no date is available. Distribution maps are included for species marked with an asterisk $\left(^{*}\right)$.

\section{Additional Notes}

Sharp-tailed Grouse. A Greater Prairie Chicken X Sharp-tailed Grouse hybird was observed at Raymore on December 24, 1971 (CP observation).

Sage Grouse. A higher Christmas Bird Count total of 30 individuals was made at Eastend on December 26, $1935 .{ }^{4}$

Chukar. These observations followed local 
